Journal of Management and Bussines (JOMB)

Volume 1, Nomor 1, Juni 2019

p-ISSN : 2656-8918

e-ISSN: $2684-8317$

DOI : https://doi.org/10.31539/jomb.v1i1.612

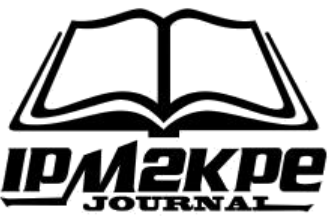

\title{
PENGARUH STRES KERJA TERHADAP VOLUNTARY TURNOVER INTENTION KARYAWAN
}

\author{
Ane Emigia Kusuma ${ }^{1}$, Erry Sunarya ${ }^{2}$, Kokom Komariah ${ }^{3}$ \\ Universitas Muhammadiyah Sukabumi ${ }^{1,2,3}$ \\ Email: emigia9533@gmail.com ${ }^{1}$
}

\begin{abstract}
ABSTRAK
Tujuan dalam penelitian ini untuk mengetahui pengaruh setres kerja terhadap voluntary turnover intention karyawan, dengan dimensi stres kerja secara parsial dan simultan.. Metode teknik analisis data yang digunakan yaitu Analisis Jalur (Path Analysis) dengan menggunakan Software SPSS 24, dan untuk pengujian hipotesis adalah uji statistik secara parsial (uji t) dan uji secara simultan (uji f). Hasil penelitian, uji t menunjukkan bahwa stres kerja melalui dimensi Konflik Peran (X1) berpengaruh positif dan tidak signifikan terhadap Voluntary Turnover Intention, Peran Yang Rancu/Tidak Jelas (X2) berpengaruh positif dan signifikan terhadap Voluntary Turnover Intention, Beban Kerja Yang Berlebihan (X3) berpengaruh positif dan signifikan terhadap Voluntary Turnover Intention. Berdasarkan uji $\mathrm{F}$ nilai sig $0,000<0,05$ yang berarti bahwa secara stres kerja secara bersama-sama (simultan) yaitu Konflik Peran (X1), peran yang rancu/tidak jelas (X2), dan beban kerja yang berlebihan (X3) berpengaruh signifikan terhadap Voluntary Turnover Intention (Y). Simpulan, secara simultan stres kerja berpengaruh positif dan signifikan terhadap voluntary turnover intention karyawan pada PT Doosan Sinar Sukabumi Kabupaten Sukabumi.
\end{abstract}

Kata Kunci: Stres Kerja, Voluntary Turnover Intention

ABSTRACT

The purpose of this study is to determine the effect of work stress on employee voluntary turnover intention, with the dimensions of work stress partially and simultaneously. The use of methods in this study is to use the type of sampling included in Simple Random Sampling and by distributing questionnaires as many as 210 respondents. The data analysis technique method used is Path Analysis by using SPSS 24 Software, and for hypothesis testing is a partial statistical test ( $t$ test) and a simultaneous test ( $f$ test). The results, the t test showed that work stress through the Role Conflict dimension (X1) had a positive and not significant effect on Voluntary Turnover Intention, the Ambiguous / Unclear Role (X2) had a positive and significant effect on Voluntary Turnover Intention, Excessive Workload (X3 ) has a positive and significant effect on Voluntary Turnover Intention. Based on the F test sig value 0,000<0,05 which means that work stress together (simultaneous) namely Role Conflict (X1), ambiguous / unclear role (X2), and excessive workload (X3) have a significant effect towards Voluntary Turnover Intention (Y). Conclusion, simultaneously job stress has a positive and significant effect on employee voluntary turnover intention at PT Doosan Sinar Sukabumi, Sukabumi Regency

Keywords: Job Stress, Voluntary Turnover Intention 


\section{PENDAHULUAN}

Perusahaan yang mampu bertahan dan bersaing adalah perusahaan yang mampu memanfaatkan sumber daya manusia yang handal dan berkinerja dengan baik dengan memberikan kenyamanan dalam bekerja atau dalam lingkungan bekerja, pemberian bonus karyawan bila mencapai target yang sudah ditentukan perusahaan dan fasilitas didalam sebuah pekerjaan seperti ketersediaan Badan Penyelenggara Jaminan Sosial (BPJS) Ketenagakerjaan, Badan Penyelenggara Jami nan Sosial (BPJS) Kesehatan, dan tunjangan yang lainnya, karena sangat mempengaruhi karyawan untuk tetap mempertahankan pekerjaan bahkan akan berpengaruh positif bagi sebuah perusahaan dalam mengurangi penyebab tingkat tingginya voluntary turnover intention karyawan dan pengrekrutan karyawan juga mengurangi biaya pelatihan sumber daya manusia yang baru.

Mengelola karyawan bukan hal yang mudah, karena karyawan mempunyai keinginan, pikiran, perasaan, status, dan latar belakang yang berbeda yang dibawa ke dalam organisasi. Adanya perbedaan kepribadian memungkinkan terjadinyakonflik dalam suatu organisasi dan hal ini merupakan sesuatu yang tidak dapat dihindari di dalam perusahaan maupun di lingkungan kerja. Oleh sebab itu, perusahaan harus lebih memperhatikan sumber daya manusia dengan meningkatkan daya saingnya melalui kualitas manajemen. Oleh karena itu kualitas manajemen ialah dengan memelihara hubungannya dengan karyawan terutama saat karyawan stres dalam menghadapi pekerjaannya. Stres kerja sangat rawan bahkan dapat menimbulkan tingginya voluntary turnover intention karyawan yang akan membuat target perusahaan menurun.

Voluntary turnover intentionkaryawan yaitu keputusan karyawan dalam meninggalkan pekerjaannya secara sukarela, disebabkan oleh beberapa faktor salah satunya stres kerja (Setyono, 2007). Tingkat voluntary turnover intention yang tinggi dapatmenyebabkan dampak negatif bagi perusahaan, karena perusahaan akan kehilangan karyawan yang berkinerja baik. Sehingga perusahaan rugi karena akan menambah biaya rekrutmen dan biaya pelatihan kembali meningkat. Karyawan dapat mengambil tindakan seperti voluntary turnover dari perusahaan jika mendapat perlakuan tidak adil dari perusahaan dan bahkan karyawan mempunyai keinginan berhenti dari perusahaan karena ingin berpindah ke lain perusahaan dan berniat mencari pekerjaan lain yang nyaman dan sesuai. 
Stres kerja sering timbul dalam pekerjaan sebagai akibat dari tekanan atau ketegangan yang bersumber dari ketidak selarasan antara karyawan dengan lingkungan pekerjaanya (Rismawan, 2014). Dilingkungan organisasi berbagai penyebab stress antara lain tekanan untuk menyelesaikan tugas dalam kurun waktu yang terbatas, beban kerja yang berlebihan, pimpinan yang menciptakan budaya ketegangan, rasa takut, dan kecemasan, rekan kerja yang tidak kompak. Dengan perkataan lain, apabila sarana dan tuntutan tugas tidak selaras dengan kebutuhan dan kemampuan karyawan, maka karyawan akan mengalami stres kerja. Stres semakin kuat apabila karyawan menghadapi masalah yang datang bertubi-tubi.

Stres kerja diduga dapat menjadi penyebab meningkatnya voluntary turnover intention karyawan dan stres yang terlalu besar akan menimbulkan voluntary turnover intention, karena stres timbul adanya tekanan dan banyak nya tuntutan kepada para karyawan dengan kondisi yang tidak menyenangkan baik secara fisik maupun mental.Penyebab stres kerja terjadi karena penggabungan dari beberapa penyebab antara lain, beban kerja yang terlalu berat, waktu kerja yang mendesak, pengawasan kerja yang kurang, iklim kerja yang tidak sehat, otoritas kerja yang tidak memadai yang berhubungan dengan tanggung jawab, konflik kerja, konflik peran, kurangnya informasi dari umpan balik tentang prestasi kerja seseorang, ketidakjelasan peranan karyawan dalam keseluruhan kegiatan organisasi, perbedaan nilai antara karyawan dengan pemimpin yang frustasi dalam kerja.

Stres kerja mempunyai pengaruh positif terhadap keinginan untuk meninggalkan organisasi (turnover intention) seperti yang diungkapkan dalam penelitian (Syahronica et al., 2015). Adanya pengaruh tersebut menunjukkan bahwa beban kerja yang berlebihan, kurang jelasnya wewenang yang diberikan tidak sesuai tanggung jawab, adanya konflik dalam organisasi, adanya perbedaan persepsi dalam pekerjaan dan kecilnya pendapatan yang diterima menimbulkan beban kerja tersendiri bagi karyawan serta menimbulkan stres yang cukup tinggi dan berdampak pada keingiannnya meninggalkan organisasi, tekanan yang relatif tinggi akan mengakibatkan masalah kesehatan fisik, kesehatan mental dan kurangnya kesejahteraan bisa mengakibatkan stres kerja, dan bisa menurunkan produktivitas karyawan. Karyawan yang stres cenderung menganggap suatu pekerjaan bukanlah sesuatu yang penting bagi mereka, sehingga tidak mampu menyelesaikan suatu pekerjaan tersebut sesuai target 
yang telah ditetapkan. Akan tetapi, tidak semua karyawan yang mengalami tekanan dalam pekerjaannya tidak mampu menyelesaikan pekerjaan tepat waktu dan sesuai dengan target yang telah ditetapkan.

Tema yang diusulkan dalam penelitian ini adalah pengaruh stres kerja terhadap voluntary turnover intention karyawan pada PT Doosan Sinar Sukabumi Kabupaten Sukabumi. Tujuan penelitian ini untuk mengukur pengaruh stres kerja terhadap voluntary turnover intention karyawan pada PT Doosan Sinar Sukabumi Kabupaten Sukabumi secara parsial dan simultan.

\section{KAJIAN TEORI}

\section{Stres Kerja}

Menurut Soesmalijah Soewondo (Suwanto dan Donni Juni, 2014) Stres kerja adalah suatu kondisi dimana terdapat saru atau beberapa faktor ditempat kerja yang berinteraksi dengan pekerja sehingga mengganggu kondisi pisiologis Dan prilaku. Stres kerja akan muncul bila terdapat kesenjangan antara kemampuan individu dengan tuntutan-tuntutan dari pekerjaannya. Stres kerja merupakan kesenjangan antara kebutuhan individu dengan pemenuhannya dari lingkungan.

\section{Voluntary Turnover Intention}

Turnover intention merupakan keinginan pekerja untuk berhenti dari perusahaan karena ingin pindah ke lain perusahaan, selain itu melakukan kegiatan pengembangan untuk mempersiapkan pencegahan voluntary turnover. Voluntary turnover yang tidak dapat dihindari akan berdampak negatif bagi perusahaan ketika jumlah investasi suatu perusahaan dibuat dalam rekrutmen, seleksi, klasifikasi dan pelatihan personil, meskipun tidak semua jenis turnover bersifat negatif.

\section{METODE PENELITIAN}

Penelitian ini dilaksanakan pada PT Doosan Sonar Sukabumi Kabupaten Sukabumi. Dalam penelitian ini terdapat dua variabel yang dijadikan kawasan penelitian yaitu stres kerja (X1) dan voluntary turnover intention (Y). Populasi dalam sampel ini adalah Karyawan PT Doosan Sinar Sukabumi Kabupaten Sukabumi. Metode yang digunakan untuk pengambilan sample dalam penelitian ini adalah teknik Simple 
Random Sampling ialah Simple (sederhana) karena pengambilan anggota sampel dari populasi dilakukan secara acak tanpa memperhatikan strata yang ada dalam populasi itu. Cara demikian dilakukan bila anggota populasi dianggap homogen.

Jenis dan sumber data penelitian ini menggunakan data dengan wawancara kepada karyawan PT. Doosan Sinar Sukabumi Kabupaten Sukabumi dan penyebaran kuesioner kepada 210 responden yang telah ditentukan dengan skala Likert dan diberi skor tertentu. Metode analisis dalam penelitian ini bersumber dari kuesioner dengan beberapa item pertanyaan dari masing masing indikator-indikator yang digunakan untuk mengukur variabel variabel penelitian, kemudian ditabulasikan dengan teknik statistik analisis jalur (Path Analisys)agar dapat menjelaskan atau menggambarkan hubungan dan pengaruh antara satu variabel dengan variabel lain, koefisien korelasi, koefisien jalur, pengaruh langsung dan tidak langsung, koefisien korelasi ganda, koefisien determinasi, analisis regresi linear berganda, dan untuk pengujian hipotesis adalah uji statistik secara parsial (uji t) dan uji secara simultan (uji f).

\section{HASIL PENELITIAN}

\section{Koefisien Korelasi}

Untuk melakukan teknik analisis, peneliti menggunakan bantuan perangkat lunak SPSS 24 sebagai berikut:

Tabel 1

Koefisien Korelasi

\begin{tabular}{|c|c|c|c|c|c|}
\hline & & $\mathrm{x} 1$ & $\mathrm{x} 2$ & $\mathrm{x} 3$ & $\mathrm{y}$ \\
\hline \multirow[t]{3}{*}{$\mathrm{x} 1$} & Pearson Correlation & 1 & $.299^{* * *}$ & $.257^{* *}$ & $.190^{* * *}$ \\
\hline & Sig. (2-tailed) & & .000 & .000 & .006 \\
\hline & $\mathrm{N}$ & 210 & 210 & 210 & 210 \\
\hline \multirow[t]{3}{*}{$\mathrm{x} 2$} & Pearson Correlation & $.299^{* * *}$ & 1 & $.365^{* * *}$ & $.417^{* * *}$ \\
\hline & Sig. (2-tailed) & .000 & & .000 & .000 \\
\hline & $\mathrm{N}$ & 210 & 210 & 210 & 210 \\
\hline \multirow[t]{3}{*}{$\mathrm{x} 3$} & Pearson Correlation & $.257^{* *}$ & $.365^{* * *}$ & 1 & $.424^{* *}$ \\
\hline & Sig. (2-tailed) & .000 & .000 & & .000 \\
\hline & $\mathrm{N}$ & 210 & 210 & 210 & 210 \\
\hline \multirow[t]{3}{*}{$\mathrm{Y}$} & Pearson Correlation & $.190^{* * *}$ & $.417^{* *}$ & $.424^{* *}$ & 1 \\
\hline & Sig. (2-tailed) & .006 & .000 & .000 & \\
\hline & $\mathrm{N}$ & 210 & 210 & 210 & 210 \\
\hline
\end{tabular}

(Sumber: Olah Data Peneliti, 2019)

Berdasarkan hasil perhitungan pada tabel 1 maka diperoleh angka korelasi antara variabel konflik peran (X1) dengan peran yang rancu/tidak jelas (X2) sebesar 
0,299, konflik peran (X1) dengan beban kerja yang berlebihan (X3) sebesar 0,257, selanjutnya diperoleh angka korelasi antar variabel peran yang rancu/tidak jelas (X2) dengan beban kerja yang berlebihan (X3) sebesar 0,365.

\section{Koefiesien Jalur}

Untuk menghitung koefisien jalur antara stres kerja yang mempengaruhi voluntary turnover intention karyawan pada PT Doosan Sinar Sukabumi Kabupaten Sukabumi yang di antaranya konflik peran (X1), peran yang rancu/tidak jelas (X2), dan beban kerja yang berlebihan (X3). Berdasarkan hasil pengolahan data menggunakan software SPSS 24 diperoleh koefisien jalur $\mathrm{X}_{1}, \mathrm{X}_{2}, \mathrm{X}_{3}$ terhadap $\mathrm{Y}$ adalah sebagai berikut:

Tabel 2

Koefien Jalur

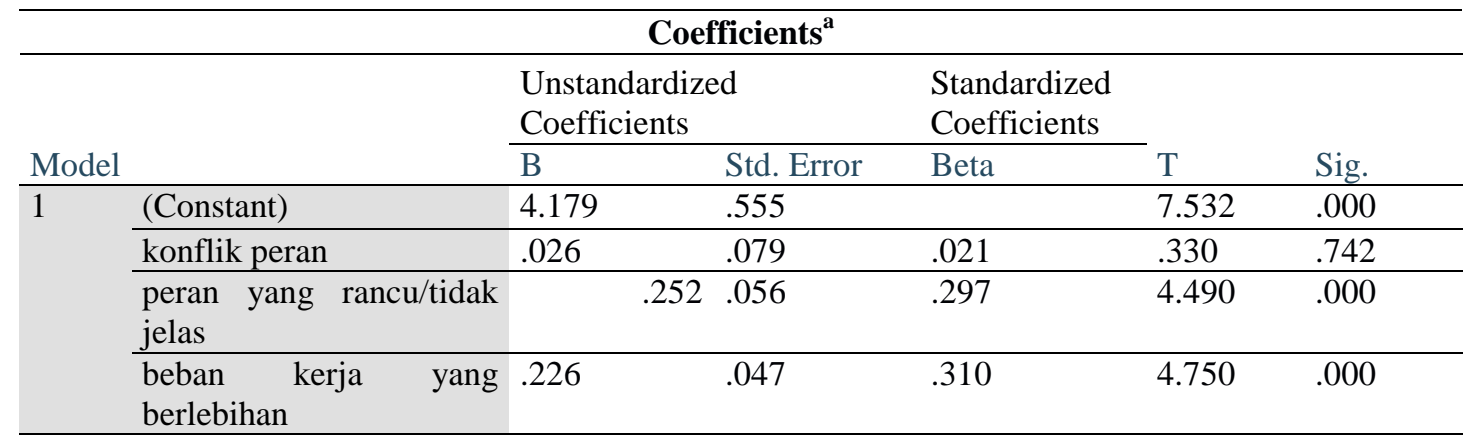

a. Dependent Variable: voluntary turnover intention

(sumber: Olah Data Peneliti, 2019)

Untuk mengetahui besarnya koefisien jalur dapat dilakukan dengan melihat nilai koefisien jalur yang di tunjukan Standardized Coefficients atau beta pada tabel 2 . Maka diketahui koefisien jalur antar variabel yakni, koefisien jalur dimensi konflik peran terhadap voluntary turnover intention (Pyx 1) sebesar 0,021, dimensi peran yang rancu/tidak jelas terhadap voluntary turnover intention (Рyx2) sebesar 0,297, dan dimensi beban kerja yang berlebihan terhadap voluntary turnover intention (Pyx3) sebesar 0,310. Nilai tersebut merupakan bobot nilai untuk pengaruh langsung antara dimensi konflik peran, peran yang rancu/tidak jelas, dan beban kerja yang berlebihan terhadap voluntary turnover intention.

\section{Pengaruh Langsung dan Tidak Langsung}

Adapun analisis dari pengaruh langsung dan tidak langsung dan total pengaruh antar variabel secara manual dapat dilihat pada tabel berikut ini. 
Tabel 3

Total Pengaruh Langsung dan Tidak Langsung $X_{1}, X_{2}, X_{3}$ Terhadap $Y$

\begin{tabular}{|c|c|c|c|c|c|c|c|}
\hline \multirow[t]{2}{*}{ Variabel } & \multirow{2}{*}{$\begin{array}{l}\text { Koef } \\
\text { Beta } \\
\end{array}$} & \multirow{2}{*}{$\begin{array}{l}\text { Pengaruh } \\
\text { Langsung }\end{array}$} & \multicolumn{3}{|c|}{ Pengaruh Tidak Langsung } & \multirow{2}{*}{$\begin{array}{c}\text { Total } \\
\text { Pengaruh } \\
\text { Tdk } \\
\text { Langsung } \\
\end{array}$} & \multirow{2}{*}{$\begin{array}{c}\text { TOTAL } \\
\text { PENGARUH }\end{array}$} \\
\hline & & & $\mathrm{X} 1$ & $\mathrm{x} 2$ & $\mathrm{x} 3$ & & \\
\hline $\mathrm{x} 1$ & 0.021 & 0.00044 & & 0.00186 & 0.00167 & 0.00353 & 0.00397 \\
\hline $\mathrm{x} 2$ & 0.297 & 0.08821 & 0.00186 & & 0.03361 & 0.03547 & 0.12368 \\
\hline $\mathrm{x} 3$ & 0.31 & 0.0961 & 0.00167 & 0.03361 & & 0.03528 & 0.13138 \\
\hline \multicolumn{7}{|c|}{ TOTAL PENGARUH } & 0.25903 \\
\hline
\end{tabular}

(Sumber: Olah Data Peneliti, 2019)

Dari tabel 3 didapatkan total pengaruh antara konflik peran (X1), peran yang rancu/ tidak jelas (X2), beban kerja yang berlebihan (X3), terhadap voluntary turnover intention (Y) adalah sebesar 0,25903 atau 25,9\%.

\section{Koefisien Korelasi Ganda}

Adapun hasil perhitungan dengan menggunakan software SPSS 24 adalah sebagai berikut:

\section{Tabel 4}

Koefisien Korelasi Antara $X_{1}, X_{2}, X_{3}$, terhadap $Y$

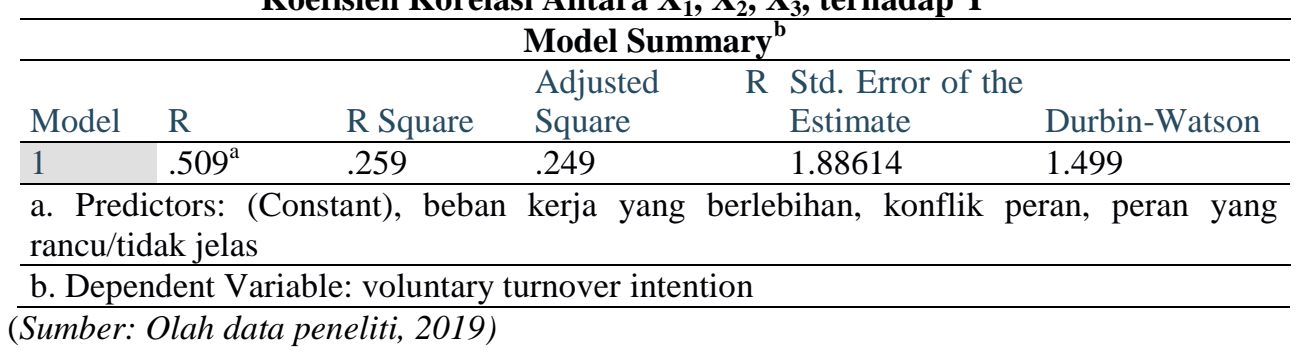

Berdasarkan hasil perhitungan pada tabel diatas, diperoleh hasil korelasi ganda yang dapat dilihat bahwa nilai $\mathrm{R}$ yang diperoleh adalah sebesar 0,509. Adapun penafsiran kuatnya atau tidaknya koefisien korelasi dapat dilihat dalam tabel di bawah in

Tabel 5

Koefisien Korelasi Menurut Guilford

\begin{tabular}{cc}
\hline Interval Koefisien & Tingkat Hubungan \\
\hline $0,80-1,0$ & Sangat Kuat \\
\hline $0,60-0,779$ & Kuat \\
\hline $0,40-0,599$ & Cukup Kuat \\
\hline $0,20-0,399$ & Rendah \\
\hline $0,00-0,199$ & Sangat Rendah \\
\hline
\end{tabular}

Sumber: Sugiyono (2014) 
Hasil perhitungan korelasi menghasilkan nilai sebesar 0,509 dengan derajat kepercayaan sebesar 95\% dan tingkat kekeliruan $5 \%$ atau $a=0,05$. Berdasarkan hal tersebut maka korelasi antara konflik peran (X1), peran yang rancu/ tidak jelas (X2), dan beban kerja yang berlebihan (X3) terhadap voluntary turnover intention (Y) terletak pada tingkat hubungan yang cukup kuat dikarenakan berada pada rentang antara 0,40 0,599 .

\section{Koefisien Determinasi}

Untuk mengetahui pengaruh konflik peran (X1), peran yang rancu/ tidak jelas (X2), dan beban kerja yang berlebihan (X3) terhadap voluntary turnover intention (Y) sehingga dilakukan perhitungan koefisien determinasi yang dapat dihitung dengan menggunakan rumus sebagai berikut :

$$
K d=r^{2} \times 100 \%
$$

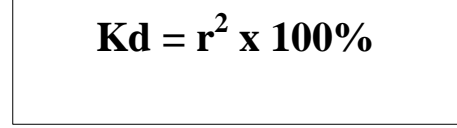

Dimana $\quad: \mathrm{Kd}=$ Koefisien Determinasi

$$
r^{2}=\text { Koefisien Korelasi }
$$

Dan dik etahui : $r=0,509$

Sehingga dapat dihitung sebagai berikut:

$$
\begin{aligned}
\mathrm{Kd} & =0,509^{2} \times 100 \% \\
& =0,259081 \times 100 \% \\
\mathrm{Kd} & =25,9 \%
\end{aligned}
$$

Adapun kriteria untuk koefisien determinasi adalah sebagai berikut, jika "Kd" mendekati 0 , maka pengaruh variabel $\mathrm{X}_{1}, \mathrm{X}_{2}$, dan $\mathrm{X}_{3}$ terhadap variabel $\mathrm{Y}$ lemah, jika "Kd" mendekati 1, maka pengaruh variabel $\mathrm{X}_{1}$ dan $\mathrm{X}_{2}$ terhadap variabel $\mathrm{Y}$ kuat. Berdasarkan perhitungan koefisien determinasi yang telah peneliti lakukan, diketahui bahwa nilai $\mathrm{Kd}=25,9 \%$ sedangkan sisanya $74,1 \%(100 \%-25,9 \%=74,1 \%)$ dari faktor yang tidak diteliti. Sehingga dapat disimpulkan pengaruh antara $\mathrm{X}_{1}, \mathrm{X}_{2}$, dan $\mathrm{X}_{3}$ terhadap Y yaitu lemah. 


\section{Analisis Regresi Linear Berganda}

Perhitungan regresi linear berganda tersebut dilakukan dengan menggunakan bantuan software SPSS 24. Adapun hasil perhitungan tersebut dapat dilihat pada tabel berikut:

Tabel 6

Hasil Perhitungan Regresi Linear Berganda

\begin{tabular}{|c|c|c|c|c|c|c|}
\hline \multicolumn{7}{|c|}{ Coefficients $^{\mathrm{a}}$} \\
\hline & & \multicolumn{2}{|c|}{$\begin{array}{c}\text { Unstandardized } \\
\text { Coefficients }\end{array}$} & \multirow{2}{*}{$\begin{array}{c}\begin{array}{c}\text { Standardized } \\
\text { Coefficients }\end{array} \\
\text { Beta } \\
\end{array}$} & \multirow{3}{*}{$\frac{\mathrm{T}}{7.532}$} & \multirow{3}{*}{$\frac{\text { Sig. }}{.000}$} \\
\hline \multicolumn{2}{|c|}{ Model } & $\mathrm{B}$ & Std. Error & & & \\
\hline \multirow[t]{4}{*}{1} & (Constant) & 4.179 & .555 & & & \\
\hline & konflik peran & .026 & .079 & .021 & .330 & .742 \\
\hline & $\begin{array}{l}\text { peran yang rancu/tidak } \\
\text { jelas }\end{array}$ & .252 & .056 & .297 & 4.490 & .000 \\
\hline & $\begin{array}{l}\text { beban kerja yang } \\
\text { berlebihan }\end{array}$ & .226 & .047 & .310 & 4.750 & .000 \\
\hline
\end{tabular}

Dari hasil output SPSS 24 di atas, dapat diketahui persamaan regresi ganda yaitu: $Y=4.179+0,026 X_{1}+0,252 X_{2}+0,226 X_{3}+$ e. Sehingga dari persamaan diatas, diketahui terdapat pengaruh positif antara $\mathrm{X}_{1}, \mathrm{X}_{2}$, dan $\mathrm{X}_{3}$ terhadap $\mathrm{Y}$. Maka voluntary turnover intention akan meningkat jika konflik peran, peran yang rancu/ tidak jelas, dan beban kerja yang berlebihan terus meningkat.

\section{Uji Secara Parsial (T)}

Untuk pengujian secara individu digunakan uji $\mathrm{T}$, bertujuan untuk mengetahui adanya pengaruh yang signifikan dari masing-masing variabel independen terhadap variabel dependen, yaitu terdiri dari stres kerja (variabel independen) dengan melalui dimensi yaitu konflik peran, peran yang rancu/tidak jelas, dan beban kerja yang berlebihan terhadap voluntary turnover intention (variabel dependen). Maka dalam penelitian ini data yang digunakan untuk perhitungan uji $\mathrm{T}$ peneliti menggunakan software SPSS 24 dengan hasil perhitungan sebagai berikut: 
Tabel 7

Hasil Perhitungan Uji Hipotesis Secara Parsial

Coefficients $^{\mathrm{a}}$

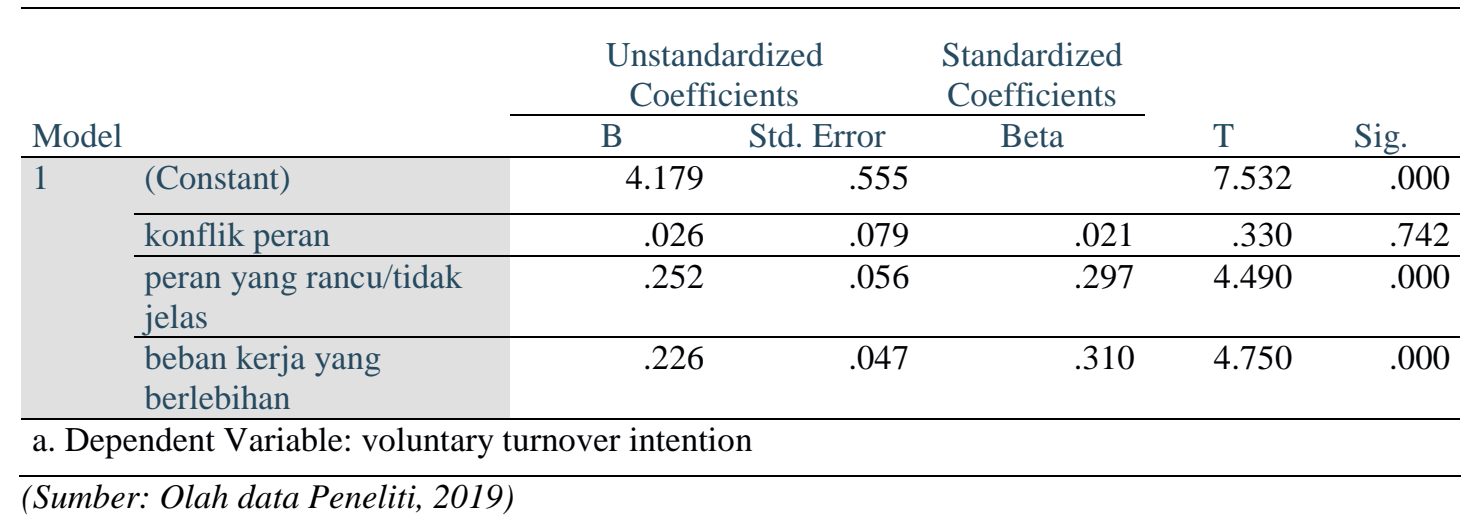

Berdasarkan hasil perhitungan untuk variabel konflik peran (X1) memiliki $\mathrm{T}_{\text {hitung }} \leq \mathrm{T}_{\text {tabel }}$ yakni $0,330 \leq 1.65$ maka $\mathrm{H}_{1}$ ditolak dan $\mathrm{H}_{\mathrm{O}}$ diterima sehingga hipotesis "terdapat pengaruh yang positif dan signifikan antara konflik peran terhadap voluntary turnover intention pada PT Doosan Sinar Sukabumi Kabupaten Sukabumi” di tolak. Kesimpulan tersebut terlihat dari nilai tidak sig $\geq 0.05$ yakni $0.742 \geq 0.05$.

Untuk variabel peran yang rancu/ tidak jelas (X2) memliki $\mathrm{T}_{\text {hitung }} \geq \mathrm{T}_{\text {tabel }}$ yakni $4.490 \geq 1.65$ maka $\mathrm{H}_{1}$ diterima dan $\mathrm{H}_{\mathrm{O}}$ ditolak sehingga hipotesis "terdapat pengaruh yang positif dan signifikan antara peran yang rancu/ tidak jelas terhadap voluntary turnover intention pada PT Doosan Sinar Sukabumi Kabupaten Sukabumi” diterima. Kesimpulan tersebut terlihat dari nilai sig $\leq 0.05$ yakni $0.000 \leq 0.05$.

Selanjutnya untuk variabel beban kerja yang berlebihan memliki $\mathrm{T}_{\text {hitung }} \geq \mathrm{T}_{\text {tabel }}$ yakni $4.750 \geq 1.65$ maka $\mathrm{H}_{1}$ diterima dan $\mathrm{H}_{\mathrm{O}}$ ditolak sehingga hipotesis "terdapat pengaruh yang positif dan signifikan antara beban kerja yang berlebihan terhadap voluntary turnover intention pada PT Doosan Sinar Sukabumi Kabupaten Sukabumi” diterima. Kesimpulan tersebut terlihat dari nilai sig $\leq 0.05$ yakni $0.000 \leq 0.05$.

\section{Uji Secara Simultan (F)}

Untuk menguji signifikan pengaruh variabel $X_{1}, X_{2}$, dan $X_{3}$ secara bersamasama terhadap variabel Y, Data yang digunakan untuk perghitungan uji $\mathrm{F}$ selanjutnya dimasukan dan dihitung melalui software SPSS 24. Adapun hasil perhitungan adalah sebagai berikut: 
Tabel 8

Hasil Perhitungan Uji Hipotesis Secara Simultan

\begin{tabular}{|c|c|c|c|c|c|c|}
\hline \multicolumn{7}{|c|}{ ANOVA $^{\mathrm{a}}$} \\
\hline Model & & Sum of Squares & Df & Mean Square & $\mathrm{F}$ & Sig. \\
\hline \multirow[t]{3}{*}{1} & Regression & 256.670 & 3 & 85.557 & 24.049 & $.000^{\mathrm{b}}$ \\
\hline & Residual & 732.854 & 206 & 3.558 & & \\
\hline & Total & 989.524 & 209 & & & \\
\hline \multicolumn{7}{|c|}{ a. Dependent Variable: voluntary turnover intention } \\
\hline \multicolumn{7}{|c|}{$\begin{array}{l}\text { b. Predictors: (Constant), beban kerja yang berlebihan, konflik peran, peran yang rancu/tidak } \\
\text { jelas }\end{array}$} \\
\hline
\end{tabular}

Berdasarkan tabel dan perhitungan diatas maka pada penelitian ini didapatkan $F_{\text {hitung }}$ sebesar 24.049, sehingga dapat disimpulkan bahwa $F_{\text {hitung }}$ lebih besar dari $F_{\text {tabel }}$, yakni $24.049 \geq 3.89$. Selain $F_{\text {hitung }}$ dari tabel 4.25 juga dapat dilihat nilai regresi memiliki tingkat signifikasi 0.000 , nilai ini lebih kecil dari 0.05 atau nilai Sig $\leq$ a. Maka dapat disimpulkan bahwa hipotesis penelitian yang menyatakan "terdapat pengaruh yang positif dan signifikan dari stres kerja terhadap voluntary turnover intention karyawan pada PT Doosan Sinar Sukabumi Kabupaten Sukabumi secara simultan" diterima. Berdasarkan Hasil penelitian menunjukan bahwa Ho ditolak dan Ha diterima, karena $\mathrm{F}_{\text {hitung }} \geq \mathrm{F}_{\text {tabel }}$.

\section{PEMBAHASAN}

Penelitian yang mengaitkan antara stres kerja dengan voluntary turnover intention karyawan telah banyak dilakukan. Namun untuk menghindari persamaan pada penelitian yang sedang dilakukan, maka peneliti akan membandingkan dengan penelitan terdahulu.

Menurut penelitian Ni Kadek Marlistiani dan Made Surya Putra (2015) yang berjudul "Pengaruh Keadilan Distributif Dan Stres Kerja Terhadap Voluntary Turnover Intention Karyawan". Penelitian ini bertujuan untuk mengetahui pengaruh mengenai stres kerja terhadap voluntary turnover intention karyawan. Hasil penelitian membuktikan bahwa stres kerja mempengaruhi voluntary turnover intention secara positif. Hasil ini sesuai dengan hipotesis dua (H2) yang menyebutkan jika stres kerja mempengaruhi voluntary turnover intention secara positif. Pengaruh positif berarti 
apabila tingkat stres kerja karyawan Werdhapura Village Center meningkat maka voluntary turnover intention karyawan akan mengalami peningkatan, dan sebaliknya.

Menurut penelitian Rutinaias Haholongan (2018) yang berjudul "Stres Kerja, Lingkungan Kerja Terhadap Turnover Intention Perusahaan". Penelitian ini bertujuan untuk menjelaskan apakah variabel stress kerja, lingkungan kerja, berpengaruh terhadap turnover intention karyawan. Hasil penelitian menunjukkan bahwa variabel stress kerja berpengaruh terhadap turnover intention dan work environment berpengaruh terhadap turnover intention kinerja karyawan dengan pengaruh sebesar 0,512.

Menurut penelitian Muhammad Khaidir dan Tinik Sugiati (2016) yang berjudul "Pengaruh Stres Kerja, Kompensasi Dan Kepuasan Kerja Terhadap Turnover Intention Studi Pada Karyawan Kontrak Pt. Gagah Satria Manunggal Banjarmasin”. Penelitian ini bertujuan untuk menganalisa pengaruh stres kerja (X1), kompensasi (X2) dan kepuasan kerja (X3) sebagai variabel independen secara parsial maupun simultan terhadap turnover intention (Y) sebagai variabel dependen pada karyawan kontrak PT. Gagah Satria Manunggal Banjarmasin. Hasil Penelitian menyimpulkan bahwa terdapat pengaruh positif yang signifikan dari masing-masing variabel independen terhadap variabel dependen. Dari ketiga variabel independen, pengaruh stres kerja paling dominan dibandingkan dengan dua variabel independen lainnya. Dan ada pengaruh signifikan secara simultan terhadap turnover intention karyawan.

Menurut penelitian Putu Agus Eka Rismawan, Wayan Gede Supartha, dan Ni Nyoman Kerti Yasa (2014) yang berjudul "Peran Mediasi Komitmen Organisasional Pada Pengaruh Stress Kerja Dan Kepuasan Kerja Terhadap Intensi Keluar Karyawan”. Penelitian ini bertujuan untuk menganalisis peran mediasi komitmen organisasional pada pengaruhnya terhadap stres kerja dan kepuasan kerja terhadap intensi keluar karyawan. Berdasarkan hasil analisis disimpulkan stres kerja berpengaruh positif dan signifikan terhadap intensi keluar, stres kerja terbukti berpengaruh negatif dan signifikan terhadap komitmen organisasional, kepuasan kerja berpengaruh negatif terhadap intensi keluar, kepuasan kerja berpengaruh positif dan signifikan terhadap komitmen organisasional dan komitmen organisaional berpengaruh negatif signifikan terhadap intensi keluar, komitmen organisasional memediasi secara parsial hubungan antara stres kerja dan kepuasan kerja terhadap intensi keluar. 
Menurut penelitian Ni Nyoman Yani Sri Lestari dan Ni Wayan Mujiati (2018) yang berjudul "Pengaruh Stres Kerja, Komitmen Organisasi, Dan Kepuasan Kerja Karyawan Terhadap Turnover Intention". Tujuan penelitian ini adalah untuk menguji pengaruh stres kerja, komitmen organisasi dan kepuasan kerja terhadap turnover intention. Penelitian ini dilakukan pada pada PT. Bank Rakyat Indonesia (Persero) Tbk. Hasil penelitian menunjukkan bahwa stres kerja berpengaruh positif dan signifikan terhadap turnover intention. Komitmen organisasi berpengaruh negatif dan signifikan terhadap turnover.

Menurut penelitian Tesha Jovi Amany (2016) yang berjudul "Pengaruh Stres Kerja, Kepuasan Tingkat Gaji Dan Kepemimpinan Terhadap Turnover Intentions Staff Auditor Di Kantor Akuntan Publik (Studi Pada Kap Di Jakarta Dan Bandung)". Penelitian ini bertujuan untuk mengetahui pengaruh stress kerja terhadap turnover intention karyawan. Hasil penelitian menunjukka bahwa Dari hasil pengujian tersebut dapat keputusan yaitu stres kerja berpengaruh positif terhadap tunover intentions.

Menurut penelitian Kevin Hill, Denis Chênevert and Jean Poitras (2015) yang berjudul "Changes In Relationship Conflict As A Mediator Of The Longitudinal Relationship Between Changes In Role Ambiguity And Turnover intentions" Tujuan Penelitian ini bertujuan untuk mengklarifikasi hubungan antara perubahan ambiguitas peran dan intensi turnover. Para penulis mengusulkan bahwa peningkatan ambiguitas peran dari waktu ke waktu dapat membuat bias interpretasi karyawan sehingga mereka melihat lebih banyak konflik hubungan di tempat kerja. Karena pentingnya hubungan sosial di tempat kerja, penulis mengusulkan bahwa peningkatan persepsi konflik hubungan ini memediasi efek positif dari peningkatan ambiguitas peran pada niat berpindah. Temuan - Hubungan positif antara peningkatan ambiguitas peran dan intensi turnover dari waktu ke waktu dimediasi oleh peningkatan konflik hubungan. Hasil memberikan penjelasan integratif dari fenomena, teori peran pemersatu, teori konflik dan teori turnover.

\section{SIMPULAN}

Secara parsial, konflik peran berpengaruh positif dan tidak signifikan terhadap voluntary turnover intention pada PT Doosan Sinar Sukabumi Kabupaten Sukabumi. Secara parsial, peran yang rancu/ tidak jelas berpengaruh positif dan signifikan terhadap 
voluntary turnover intention pada PT Doosan Sinar Sukabumi Kabupaten Sukabumi. Secara parsial, beban kerja yang berlebihan berpengaruh positif dan signifikan terhadap voluntary turnover intention pada PT Doosan Sinar Sukabumi Kabupaten Sukabumi . Secara simultan, stres kerja berpengaruh positif dan signifikan terhadap voluntary turnover intention pada PT Doosan Sinar Sukabumi Kabupaten Sukabumi.

\section{DAFTAR PUSTAKA}

Rismawan, Putu Agus Eka. Wayan Gede Supartha., dan Ni Nyoman Kerti Yasa. (2014). "Peran Mediasi Komitmen Organisasional Pada Pengaruh Stress Kerja Dan Kepuasan Kerja Terhadap Intensi Keluar Karyawan" E-Jurnal Ekonomi dan Bisnis, 3 (8), 424-441.

Setyono, Agus et, all. (2007). “Analisis Faktor-Faktor Yang Mempengaruhi Job Stress Serta Pengaruhnya Terhadap Kepuasan Kerja Dan Kinerja Salesman (Studi Kasus Pada Pt. Adira Finance Cabang Bangkong Semarang)" Jurnal Studi Manajemen \& Organisasi, 4(2), 70-80

Syahronica, Gabriela. Moehammad Soe'oed Hakam., dan Ika Ruhana. (2015). "Pengaruh Kepuasan Kerja Dan Stres Kerja Terhadap Turnover Intention (Studi Pada Karyawan Departemen Dunia Fantasi Pt Pembangunan Jaya Ancol, Tbk)" Jurnal Administrasi Bisnis, 20(1), 1-6

Sugiyono. (2014). Metode Penelitian Kuantitatif, Kualitatif, dan Kombinasi. Bandung: Alfabeta.

Suwanto, H. dan Donni Juni Priansa. (2014). Manajemen S DM dalam Organisasi Publik dan Bisnis. Bandung: Alfabeta. 